\title{
Terapi Tersenyum Untuk Mengurangi Kecemasan Lansia Di Wilayah Bantul Yogyakarta
}

\author{
Sri Setyowati *, Nasrul Hakim \\ STIKES Surya Global Yogyakarta \\ *Corresponding Email: setyoku.sg@gmail.com
}

\begin{abstract}
ABSTRAK
Kecemasan adalah perasaan yang tidak menyenangkan atau ketakutan yang tidak jelas dan hebat. Relaksasi dengan terapi tersenyum dapat memberikan respon relaksasi dan ketenangan yang akan membawa pengaruh terhadap rangsangan pada system saraf otonom yang berdampak pada respon fisiologi tubuh sehingga terjadi penurunan tekanan darah, denyut nadi dan pernapasan. Tujuan pengabdian kepada masyarakat ini untuk membantu lansia mengurangi rasa cemas secara mandiri. Sebelum dan sesudah dilakukan terapi tersenyum dilakukan pengukuran tingkat kecemasan pada lansia. Terapi tersenyum dilakukan selama 40 kali hitungan dengan yang dilakukan selama 20 kali. Hasil pengabdian kepada masyarakat dengan tema terapi tersenyum efektif untuk menurunkan kecemasan pada lansia di wilayah Timbulharjo Sewon Bantul.
\end{abstract}

Kata Kunci: Kecemasan; Lansia, Terapi Tersenyum.

\begin{abstract}
Anxiety is an unpleasant feeling or fear that is unclear and intense. Relaxation with smiling therapy can provide a relaxation and calm response which will have an influence on stimulation of the autonomic nervous system which has an impact on the body's physiological response resulting in a decrease in blood pressure, pulse and respiration. The purpose of this community service is to help the elderly independently reduce anxiety. Before and after smiling therapy, the anxiety level of the elderly was measured. Smile therapy is carried out for a count of 40 times with that of being carried out for 20 times. The result of community service with the theme of smiling therapy is effective in reducing anxiety in the elderly in the Timbulharjo Sewon area, Bantul.
\end{abstract}

Keywords: Axniety;.Elderly; Smilling Therapy

\section{PENDAHULUAN}

Usia lanjut merupakan tahap akhir dalam kehidupan manusia. Banyak lansia yang produktif dan secara fisik dalam kondisi baik, namun banyak pula lansia yang masuk dalam paradigma belas kasihan (Kholifah, 2016). Berdasarkan data survei Badan Pusat Statistik (BPS), sebanyak 60\% lansia berpendapat rendah dan tidak stabil. Kondisi ini dapat menjadi faktor rawan jatuh miskin (Badan Pusat Statistik, 2020). Melihat kondisi lansia di Indonesia menunjukkan lansia masih jauh dari mandiri dan sejahtera. Berbagai upaya telah direncanakan pemerintah untuk lansia Indonesia, empat langkah tersebut adalah langkah preventif, protektif, promotif, dan transformatif (Manalu, 2019).

Proses menua merupakan suatu proses yang disertai adanya penurunan kondisi fisik, psikologis maupun sosial yang saling berinteraksi satu sama lain. Kondisi ini akan berpotensi menimbulkan masalah kesehatan secara umum maupun kesehatan jiwa secara khusus pada lansia (Canuto et al., 2018). Salah satu masalah kesehatan jiwa yang sering terjadi pada lansia adalah 
kecemasan. Kecemasan merupakan suatu kondisi emosi yang menimbulkan ketidaknyamanan ditandai dengan perasan khawatir, kegelisahan dan ketakutan sehingga dapat mengganggu kehidupan (Annisa \& Ifdil, 2016).

Kecemasan yang dialami lansia cenderung pada perasaan kekhawatiran yang tidak jelas, yang berkaitan dengan perasaan tidak pasti dan tidak berdaya terhadap satu kondisi karena tidak memiliki objek yang spesifik. Kecemasan pada lansia dapat digunakan sebagai respon emosional terhadap penilaian dari perasaannya (Setiyowati, 2019).

Stuart \& Sundeen menyatakan dampak dari kecemasan dapat menimbulkan respon fisiologis yaitu sistem kardiovaskuler, pernapasan, neuromuskuler, gastrointestinal, saluran perkemihan, integument (kulit), respon pada sistem perilaku, sistem kognitif dan sistem afektif (Arifiati \& Wahyuni, 2020). Kecemasan kronik dapat mempersulit dan mengganggu aktivitas kehidupan sehari-hari lansia. Kecemasan pada lansia dapat menurunkan atau menyebabkan kerusakan kognitif, serta dapat terganggunya emosi dan peran sosial. Kecemasan yang tidak sejalan dengan kehidupan, berlangsung lama dan terus menerus, dapat menimbulkan kelelahan bahkan kematian (Sulistiyaningsih, Rasyid, Amalia, \& Fitria, 2020). Beberapa upaya untuk mendorong lansia hidup bahagia, sehat dan sejahtera telah dimodifikasi dalam bentuk pencegahan dan merawat dari masalah kesehatan terhadap perasaan kecemasannya. Upaya pencegahan tersebut bisa dilakukan dengan pemberian obat (farmakologi) atau nonfarmakologi.

Dalam kegiatan pengabdian kepada masyarakat ini pelaksana menggunakan terapi non farmakologi sebagai intervensi yang diberikan. Berbagai referensi menunjukkan terapi humor adalah salah satu terapi nonfarmakologi yang dapat mengurangi tingkat kecemasan lansia. Association for Applied and Therapeutic Humor (AATH) menyatakan bahwa humor menjadi intervensi terapeutik dengan cara menggunakan stimulus untuk merangsang ekspresi senang, gembira. Bennet menyatakan terapi humor dapat digunakan merangsang tertawa dapat menjadi terapi efektif menurunkan stres dan rasa cemas dan meningkatkan kualitas hidup (Hardi, Sutrisno, \& Amrullah, 2018). Intervensi ini dapat meningkatkan kesehatan lansia dan sebagai pengobatan komplementer penyakit dengan memfasilitasi penyembuhan fisik, emosional, kognitif, sosial dan spiritual.

Berdasarkan hasil lapangan didapatkan kecemasan juga dialami oleh beberapa lansia wilayah Timbulharjo Sewon Bantul. Tujuh orang lansia menyatakan sering mengalami cemas terhadap kondisi kehidupan dan kesehatannya, lima diantaranya menyatakan menganggap kondisi cemas itu mengganggu kenyamanan dalam menjalankan aktivitas sehari-hari. Tiga orang menyatakan cemas yang dirasakan akan hilang sendiri dan tidak dilakukan terapi untuk menghilangkan perasaan tersebut.

Adanya masalah yang ditemukan maka pelaksana tertarik membantu memberikan intervensi untuk mengatasi kecemasan yang dihadapi lansia wilayah Timbulharjo Sewon Bantul. Terapi tersenyum dipilih sebagai terapi dalam kegiatan ini. Terapi ini diberikan karena tersenyum merupakan salah satu cara yang paling mudah untuk mengurangi stress dan menambah teman. Manfaat terapi tersenyum dapat memberikankan respon relaksasi dan ketenangan yang akan membawa pengaruh terhadap rangsangan pada system saraf otonom yang berdampak pada respon fisiologi tubuh sehingga terjadi penurunan tekanan darah, denyut nadi dan pernapasan. Pengabdian masyarakat ini bertujuan untuk membantu lansia mengurangi rasa cemas yang bisa dilakukan secara mandiri.

\section{METODE}

Terapi tersenyum merupakan intervensi yang diberikan pada kegiatan pengabdian kepada masyarakat ini. Sasaran kegiatan pengabdian kepada masyarakat ini adalah lansia di Timbulharjo Sewon Bantul Yogyakarta sebanyak 30 lansia. Kegiatan ini dilaksanakan pada tanggal 13 Maret 2020 jam 13.00 sampai selesai. Terapi tersenyum dilakukan sebanyak 1 kali pertemuan dengan alokasi kegiatan terapi tersenyum dilakukan selama 40 kali hitungan dan dilakukan sebanyak 20 kali. Sebelum dan sesudah terapi tersenyum dilakukan pengukuran tingkat kecemasan 
menggunakan instrumen depression anxiety stress scales (DASS) untuk memantau keberhasilan atau keefektifannya.

\section{PELAKSANAAN DAN PEMBAHASAN}

Pengabdian kepada masyarakat dengan tema terapi senyum untuk mengurangi kecemasan pada lansia ini dilakukan di balai pertemuan warga Timbulharjo Sewon Bantul Yogyakarta. Pada kegiatan pengabdian kepada masyarakat intervensi berupa terapi tersenyum dilakukan dalam 1 kali pertemuan sebanyak 20 senyuman, setiap senyuman diberikan waktu 40 hitungan.

Pengambilan intervensi ini didasarkan pada artikel dari Santoso (2021) yang menyatakan senyum bukan sekadar gerakan bibir yang tersungging, namun juga menjadi kerja otak dan emosional seseorang. Orang yang bahagia tersenyum antara 40-50 kali dalam sehari dan rata-rata pada umunya, orang tersenyum sebanyak 20 kali sehari.

Berikut ini dokumentasi kegiatan terapi senyum yang telah dilakukan :

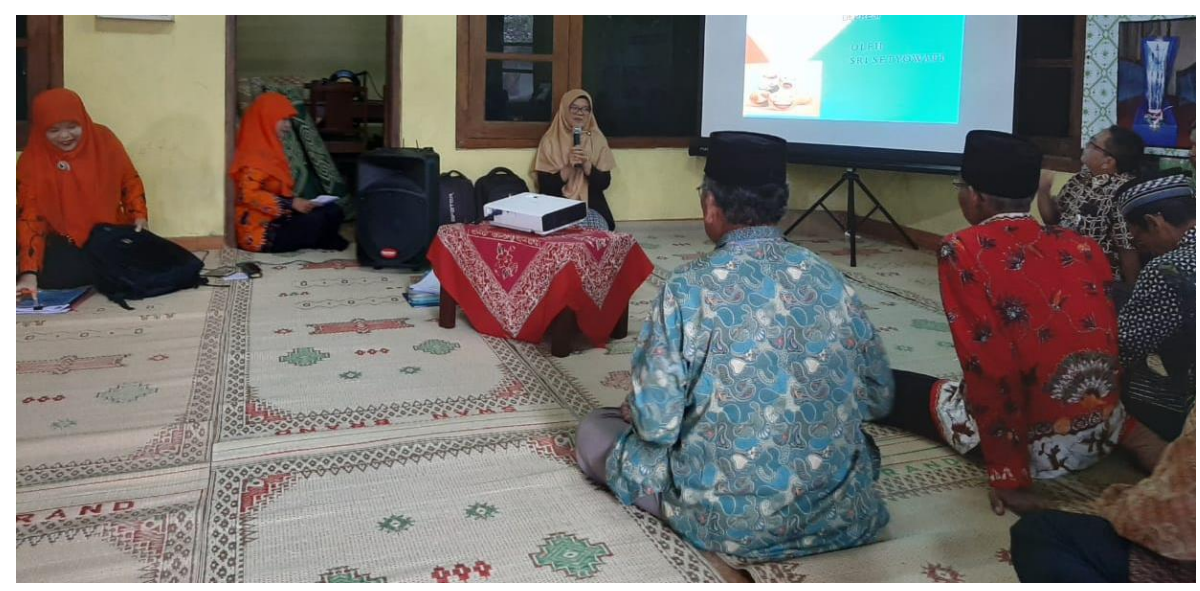

Gambar 1. Penyampaian Manfaat Terapi Tersenyum Untuk Mengurangi Kecemasan

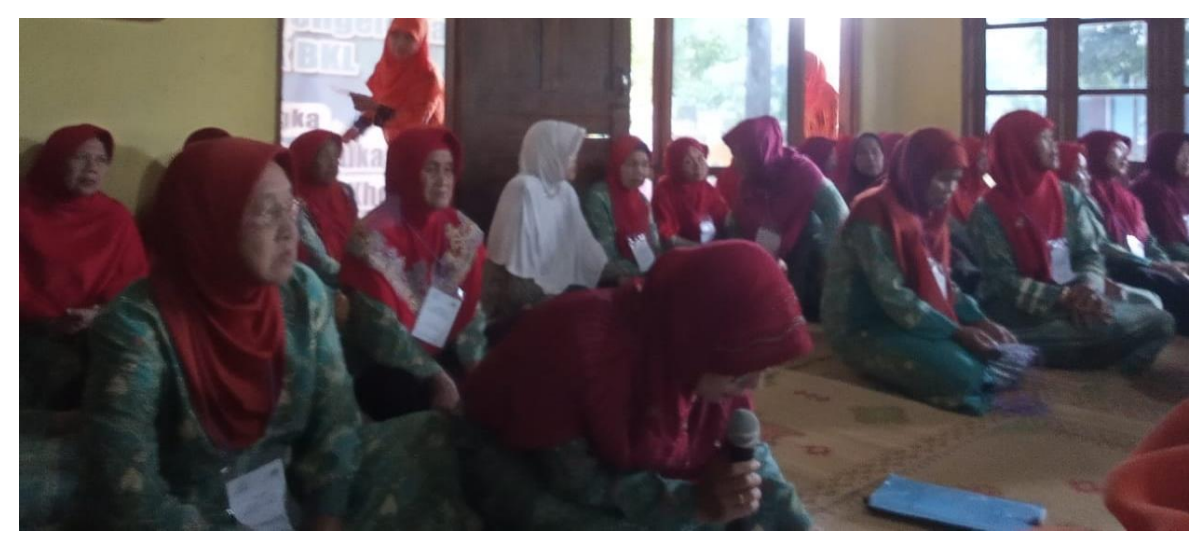

Gambar 2. Demonstrasi Terapi Senyum Untuk Mengurangi Kecemasan

Hasil pengukuran tingkat kecemasan sebelum dan sesudah terapi tersenyum pada 30 lansia di wilayah Timbulharjo Sewon Bantul ditunjukkan dalam diagram di bawah ini : 


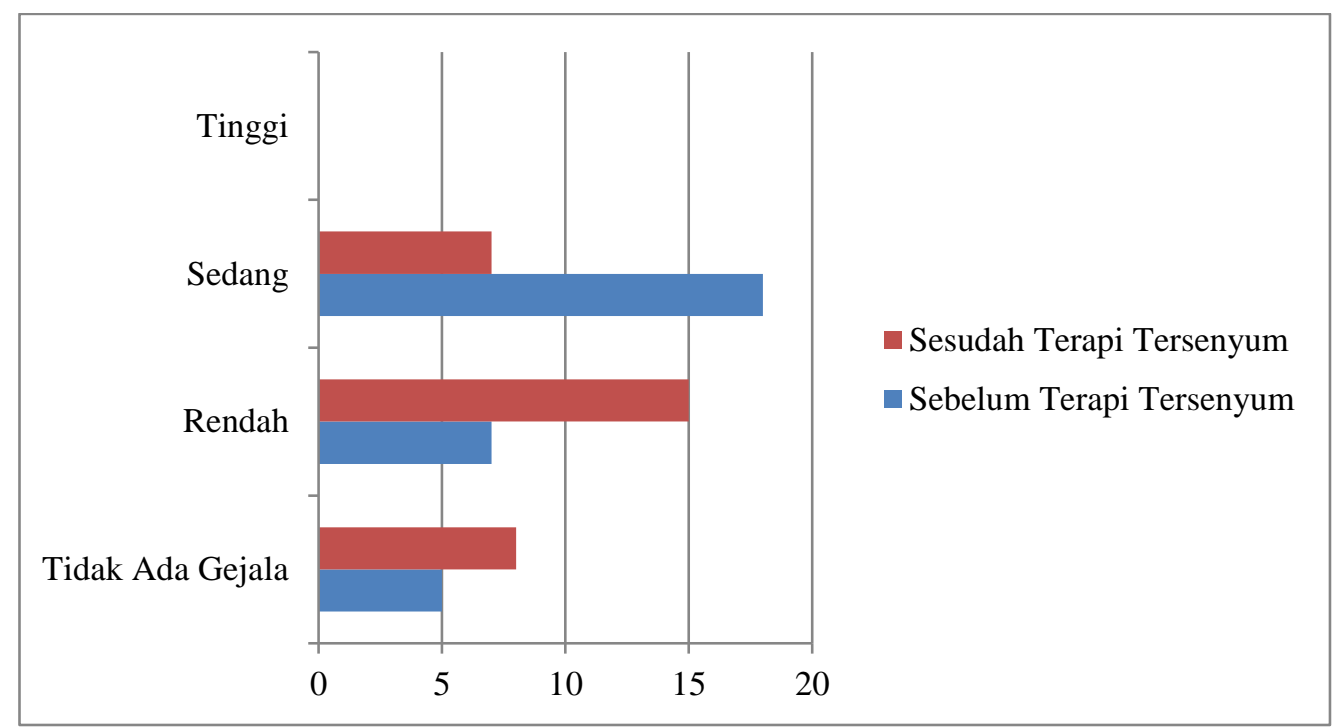

Diagram 1. Tingkat Kecemasan Lanisa Sebelum dan Sesudah Terapi Tersenyum

Melihat hasil yang ada menunjukkan bahwa terapi tersenyum efektif digunakan untuk menurunkan kecemasan pada lansia di wilayah Timbulharjo Sewon Bantul. Setelah terapi senyum, tingkat kecemasan lansia semakin menurun, terdapat jumlah peningkatan angka lansia yang tidak bergejala dan lanisa dengan kategori kecemasan yang rendah serta penurunan angka kecemasan kategori sedang.

Senyum adalah simbol adanya muatan emosional positif yang sangat tinggi dan kuat, karena mengandung emosional tinggi, tidak semua orang mampu tersenyum dengan baik. Tersenyum dapat meningkatkan kesehatan seseorang dan membuat hidupnya lebih menyenangkan. Banyak manfaat yang didapatkan dari tersenyum antara lain senyum bisa meredakan stress, senyum meningkatkan sistem kekebalan tubuh, senyum menurunkan tekanan darah, senyum bisa melepaskan endorfin, penghilang rasa sakit dan serotonin, dan Senyum akan membuat orang lebih positif dan mengurangi pikiran negatif (Hasanat, 2016).

Orang yang cemas atau stress bisa terlihat dari wajahnya, tapi dengan tersenyum bisa mencegah seseorang tampak letih dan lelah sehingga lebih mampu mengambil tindakan. Tersenyum bisa membantu sistem kekebalan tubuh untuk bekerja lebih baik. Ketika seseorang tersenyum maka fungsi imun meningkat yang membuat seseorang merasa lebih rileks dan terhindar dari penyakit.

Beberapa studi telah menunjukkan dengan seseorang tersenyum bisa melepaskan endorfin, senyawa yang bisa mengurangi rasa sakit secara alami dan serotonin. Ketiganya bisa membuat orang merasa lebih baik dan menjadi obat yang alami. Dengan mengurangi depresi, stress dan perasaan khawatir maka kesehatan seseorang juga akan meningkat dan menghindarinya dari berbagai risiko penyakit (Abdurachman, 2018).

\section{SIMPULAN}

Sebanyak 30 lansia mengikuti terapi tersenyum sampai selesai, dan dianjurkan untuk meneruskan atau melakukan secara mandiri di rumah. Terapi tersenyum menunjukkan hasil yang efektif untuk menurunkan tingkat kecemasan pada lansia.

\section{UCAPAN TERIMAKASIH}

Ucapan terimakasih disampaikan kepada kepada seluruh lansia yang ikut berpartisipasi dalam kegiatan ini dan kepada LPPM STIKES Surya Global yang telah memberikan support dana pada kegiatan ini. 


\section{DAFTAR PUSTAKA}

Abdurachman. (2018). Anatomi Senyum : Kajian Kinesiologi (2nd ed.). Airlangga University Press. Annisa, D. F., \& Ifdil, I. (2016). Konsep Kecemasan (Anxiety) pada Lanjut Usia (Lansia). Konselor, 5(2), 93. https://doi.org/10.24036/02016526480-0-00

Arifiati, R. F., \& Wahyuni, E. S. (2020). Peningkatan Sense of Humor untuk Menurunkan Kecemasan pada Lansia. IJIP: Indonesian Journal of Islamic Psychology, 1(2), 139-169. https://doi.org/10.18326/ijip.v1i2.139-169

Badan Pusat Statistik. (2020). Persentase Penduduk Miskin Maret 2020 Naik Menjadi 9,78 persen. Retrieved from https://www.bps.go.id/pressrelease/2020/07/15/1744/persentase-pendudukmiskin-maret-2020-naik-menjadi-9-78-persen.html

Canuto, A., Weber, K., Baertschi, M., Andreas, S., Volkert, J., Dehoust, M. C., ... Härter, M. (2018). Anxiety Disorders in Old Age: Psychiatric Comorbidities, Quality of Life, and Prevalence According to Age, Gender, and Country. American Journal of Geriatric Psychiatry, 26(2), 174-185. https://doi.org/10.1016/j.jagp.2017.08.015

Hardi, F., Sutrisno, \& Amrullah, A. E. (2018). Jurnal Kesehatan dr. Soebandi. Jurnal Kesehatan Dr. Soebandi, 6(2), 49-54.

Hasanat, N. U. (2016). ANDA SEDANG BERSEDIH? COBALAH TERSENYUM ATAU TERTAWA...(Suatu bukti dari Facial Feedback Hypothesis). Journal UGM, 5(2), 26-31. https://doi.org/10.22146/bpsi.13554

Kholifah, S. N. (2016). Modul Bahan Ajar Cetak Keperawatan Keperawatan Gerontik. (A. Sosiawan, Ed.), Pusdik SDM Kesehatan (Pertama, Vol. 53). Jakarta Selatan: Pusdik SDM Kesehatan. $\quad$ Retrieved from http://publications.lib.chalmers.se/records/fulltext/245180/245180.pdf\%0Ahttps://hdl.handle. net/20.500.12380/245180\%0Ahttp://dx.doi.org/10.1016/j.jsames.2011.03.003\%0Ahttps://doi. org/10.1016/j.gr.2017.08.001\%0Ahttp://dx.doi.org/10.1016/j.precamres.2014.12

Manalu, S. W. (2019). Mensos Usulkan Batasan Usia Lansia Jadi 65 Tahun. Retrieved from https://kemensos.go.id/mensos-usulkan-batasan-usia-lansia-jadi-65-tahun

Santoso, D. (2021). Ilmu Tersenyum: Panduan Untuk Gestur Senyuman Terkuat Di Dunia. Retrieved from https://smartpresence.id/blog/bisnis/ilmu-tersenyum-panduan-untuk-gestursenyuman-terkuat-di-dunia

Setiyowati, I. (2019). Cognitive Restructuring Untuk Pengendalian Kecemasan Pada Lansia. In Psikologi Sosial Di Era Revolusi Industri 4.0 : Peluang \& Tantangan (pp. 90-94).

Sulistiyaningsih, R., Rasyid, A. S., Amalia, D. N., \& Fitria, F. (2020). The Anxiety Dynamics amongst the Elderly during the Covid-19 Pandemic. Knowledge E Social Sciences ICoPsy, 2020, 326-335. https://doi.org/10.18502/kss.v4i15.8221 